\section{Health technology assessment (HTA) organizations: dimensions of the institutional and political framework}

\author{
Organizações de avaliação de tecnologias em \\ saúde (ATS): dimensões do arcabouço \\ institucional e político
}

\section{Organizaciones de evaluación de tecnologías en salud (ETS): dimensiones del marco institucional y político}

\begin{abstract}
Health technology assessment (HTA) is consolidated as a scientific and technological practice. The aim of this study is to identify HTA organizations from different settings and analyze their relevant dimensions in terms of effectiveness/impact, in order to address the challenges they face in Brazil. Narrative literature review based on data and websites of HTA organizations. There are well-established activity development processes in all organizations. These activities have specific features in their profile, in the process of technology assessment, decision and implementation of technologies that influence their potential impact on health systems. Agencies share in common the challenges of ranking the technologies to be assessed, and the implementation of their recommendations. Technical and political strengthening of the institutionalization of HTA in Brazil may foster scientific, technological and innovation policies, effectively impacting health policies.
\end{abstract}

Health Technology Assessment; Decision Making; Public Health Policy; Sustainable Development; Innovation
Hillegonda Maria Dutilh Novaes 1,2 Patrícia Coelho de Soárez 1,2

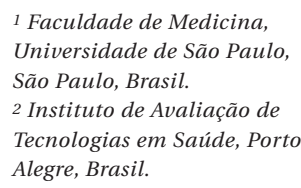

1 Faculdade de Medicina, Universidade de São Paulo São Paulo, Brasil. 2 Instituto de Avaliação de Tecnologias em Saúde, Porto Alegre, Brasil. 


\section{Introduction}

Over the last three decades, health technology assessment (HTA) has become more visible and disseminated in Europe, North America, Australia, and more lately in developing countries in terms of the development of knowledge and health policies 1. HTA plays a role in the incorporation and utilization of health technology processes, by contributing to the equitable provision and access to healthcare services, more efficiency in the allocation of resources, better effectiveness and quality of services, and stronger financial sustainability of the healthcare system.

HTA has consolidated itself as a scientific and technological practice, achieving methodological development and having expanded its influence in the scientific milieu and among healthcare managers. However, its implementation as a healthcare policy still faces difficulties. The creation of HTA organizations and agencies has been an institutionalization strategy to address the challenge of making it an effective healthcare policy.

The development of HTA organizations and its process of institutionalization may be observed in the creation of networks and the progressive increase in the number of agencies that are members of the International Network of Agencies for Health Technology Assessment (INAHTA), currently with 55 member agencies; the European Network for Health Technology Assessment (EUnetHTA), with 51 member organizations; and the more recent Health Technology Assessment Network of the Americas (RedETSA), established in 2011, with 25 member institutions 2 .

The main reason why governments justify the creation of HTA agencies is the need to have an instance with the specific purpose of informing policy makers about the development, dissemination and use of health technologies. With the intention of serving as " $a$ bridge between the world of research and the world of decision-making" 3 (p. 1464), these organizations would be situated at the border between the domains of research and policy formulation to respond to requests that require more informed, transparent and legitimate decisions, and that allow for a stronger participation of society 4,5 .

The expansion of agencies as organizational bodies within public services was not limited to HTA, and was an international phenomenon, present in different segments of economic activity. The creation of the agencies represented a major change in management policies of a number of countries where, typically, decisions on public policy were taken almost exclusively within the orbit of the public sector directly by the public administration, whether ministries or equivalent bodies. The delegation to the agencies of the mandate to coordinate technical activities is seen as part of a movement towards better governance, aiming at reducing the interference of political difficulties in activities that require stability and continuity to be successful 6 .

Many times, the results of HTA processes may be unwelcomed by some sectors or stakeholders. The reactions of some of these stakeholders to undesirable conclusions may place the agencies at risk in regards to their stability and independence 7,8 . Decision-makers, public managers, and associations of medical specialties and patients may be unaware of some aspects of the assessment process, including the economic analysis. The lack of understanding of the decision-making process and the cost-effectiveness assessments was mentioned as one of the factors that prompted criticism of the decisions 9 .

Even though most HTA agencies are scientifically independent, they operate in broader governance structures, and are not politically independent. The institutional governance structure affects the independence of the agencies, as well as the power and control of other players, such as the judicial system and regulatory bodies.

There are no standardized models or universal paths for the development and institutionalization of agencies, given the major differences among countries (cultures and values, healthcare systems, political priorities, governance, etc.). Despite the differences in the settings HTA is being developed, existing and future HTA organizations may learn one from the other. The purpose of this paper is to identify HTA organizations that are representative of the different settings, how they are shaped within the institutional and political healthcare systems framework and, by assessing their effectiveness/impact, analyse them according to their relevant dimensions, thus aiding in facing the challenges arising in the domestic context.

\section{Method}

\section{Narrative literature review}

The reference search was conducted from October 2014 to February 2015, in five databases: MEDLINE, LILACS, and the databases of the Centre for Reviews and Dissemination (CRD: NHS EED, HTA, DARE). A specific review of the HTA-specialized international journal International Journal of Technology Assessment in Health Care was made. We reviewed the references of the selected articles and asked indications from 
area experts. We also searched the gray literature in Google and academic Google. For our search, we used the following set of key words: "Technology Assessment Biomedical”, "Health Technology Assessment”, "HTA”, “Technology Assessment”, "HTA Agencies", "HTA organizations", "HTA Programs", "Evaluation”, "Decision-making”, "Health policy" and "Impact".

We also consulted the websites of INAHTA; Health Technology Assessment International (HTAi); EUnetHTA; and those of ten HTA organizations: Pharmaceutical Benefits Advisory Committee (PBAC), Australia; Swedish Council on Technology Assessment in Health Care (SBU), Sweden; Canadian Agency for Drugs and Technologies in Health (CADTH), Canada; National Institute for Clinical Excellence (NICE), United Kingdom; Agency for Healthcare Research and Quality (AHRQ), United States; Institute for Quality and Efficiency in Health Care (IQWiG), Germany; Centro Nacional de Excelencia Tecnológica en Salud (CENETEC), Mexico; Haute Autorité de Santé (HAS), France; National Committee for Health Technology Incorporation (CONITEC), Brazil; and the Institute of Health Technology Assessment (IETS), Colombia.

These organizations were selected to further the literature-review based analysis. These are pioneer HTA agencies that have influenced the models adopted in other countries, and organizations more recently created, in different healthcare system models: universal system (Beveridgian type: Sweden, United Kingdom, Australia); social security system (Bismarckian type: France, Germany); free-competition market system (United States); and hybrid system (Mexico, Brazil, Colombia). The institutional contexts of these agencies are highly variable, presenting differences in the organization of the HTA process "chain of assessment" stages (priorization, evaluation, appreciation, dissemination, and implementation of results/recommendations) 10,11 .

Based on Hailey's theoretical model 11 that lists the dimensions (structure, processes, results, product impact, and outcomes) that determine the effectiveness of HTA programs/agencies, we have selected for analysis the most frequently used parameters in the assessments: context, human resources/personnel, financial resources, organizational structure, selection and priorization, formulation of HTA issues/scope of the assessment, HTA products and utilization of HTA products 12 (Figure 1 and Table 1 ).

We present the profile of the 10 selected HTA organizations, summarizing the dimensions: assessed technology, starting date, organization accountable for the assessment, type of organization, financing, organization accountable for the appraisal, role and organization accountable for the overall decision, for the identification of types of agencies, and similarities or differences that are present in the domestic scenario.

\section{Results and discussion}

\section{Development of HTA organizations within the international perspective}

The narrative literature review identified HTA organizations that represented different contexts, and allowed the systematization of their main institutional characteristics.

The organization considered as pioneer is the PBAC, an independent statutory body established by the Australian government in 1953, to recommend new medications for the national medication formulary of the Pharmaceutical Benefits Scheme (PBS), a governmental program that subsidizes most prescription medication in Australia. No new medication can be included in the formulary without a positve recommendation by PBAC. To recommend a medication, PBAC takes into account the medical conditions for which the medication was registered, for use in Austrália, its clinical efficacy, safety and cost-effectiveness versus other treatments.

Considered the first national HTA agency in Europe, the SBU was established in 1987 with the purpose of informing the central Swedish government and district councils on the value of health technologies. The agency should provide evidence-based information on health technologies to guide health policies and practices, and the population in general. The government gave explicit instructions for the SBU: to scientifically assess new and existing health technologies considering the medical, social, economic and ethical aspect, but with no regulatory mandate 13 .

In 1989 the Canadian HTA Agency, Canadian Coordinating Office for Health Technology Assessment - CCOHTA (renamed Canadian Agency for Drugs and Technologies in Health - CADTH in 2006) was established, and funded by federal, provincial and territorial governments, with the mission of providing evidence-based assessments of new technologies, including medication, medical devices, procedures and systems for all government levels. All new medication, except cancer drugs, should be assessed prior to inclusion in the covered list. However, only part of these technologies undergoes formal reviews of clinical performance and cost-effectiveness. CADTH recommendations are consultive in nature, and it is up to the Ministry of Health and provincial governments to decide about the incorporation of 


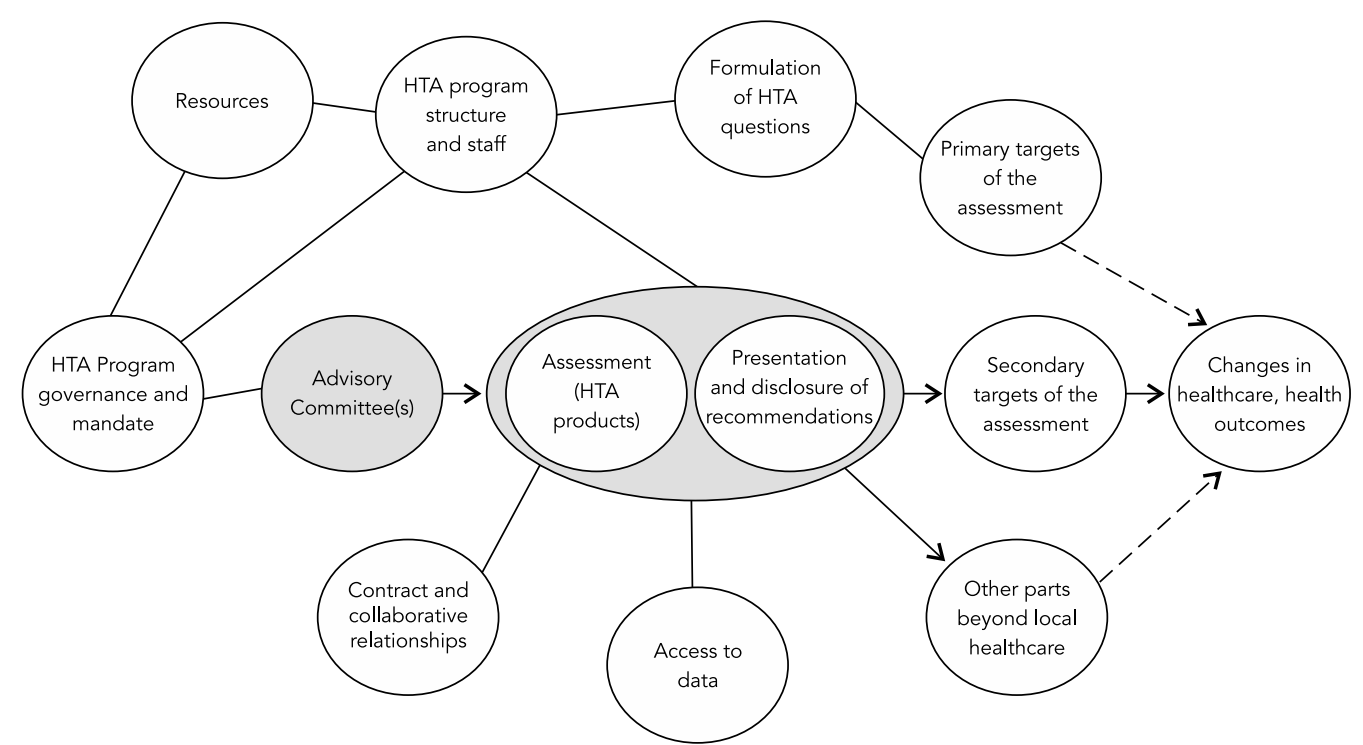

Source: adapted from Hailey 11.

technologies into the healthcare system or public plans of medication dispensation 14,15.

In 1999, the NICE, the HTA organization, whose goals are mostly connected to HTA policies and practices, was established in the United Kingdom 16,17. This organization is renowned worldwide by its methodological rigor, particularly by its assessment guidelines that are used as models globally. NICE recommendations must be complied with. The recommended technologies should be made available up to three months after the recommendation is published.

In the United States, HTA is a highly decentralized process conducted by a number of stakeholders, including governmental agencies, insurance companies and private healthcare plans, and for-profit and not-for-profit private organizations. The AHRQ was established in 2003, and is the main American government agency accountable for HTA development and funding. AHRQ assessments are typically used by the Centers for Medicare and Medicaid Services (CMS) to inform coverage policies for national and local Medicare programs. The AHRQ makes no recommendations 18 .

The IQWiG is an independent institute that investigates the benefits and risks of medical interventions on patients. The scope of its activi- ty is defined by law, and its mandate is from the Federal Joint Committee (Gemeinsamer Bundesausschuss - G-BA) or Germany's Federal Health Ministry. The IQWiG assesses surgical and diagnostic procedures, pharmaceutical products, and treatment guidelines, and sets the bases for new disease management programs. The IQWiG assessments are the basis for decision-making by the G-BA 19 .

In 2005 the French government established the HAS, an independent public body with financial autonomy. Its mandate is to carry out specific assignments, reporting to the Government and the Parliament. Its activities range from the assessing medications, medical devices and procedures to publishing guidelines for accreditation of health organizations and medical certification. It is closely connected to health government agencies, national health insurance research institutes, health practitioners' unions and patient associations. It houses some specific scientific committees, such as the Commission de la Transparence (CT), responsible for evaluating medications.

In Latin America, the agency development process started out belatedly. In 2004, the CENETEC was established in Mexico, a specialized agency within the Ministry of Health, 
Dimensions of the health technology assessment (HTA) programs/agencies

\begin{tabular}{|c|c|c|c|c|}
\hline Structure & Processes & Results & Product impact & Final outcomes \\
\hline $\begin{array}{l}\text { - Mandate - Target- } \\
\text { population }\end{array}$ & Process management: & Screening on the horizon & $\begin{array}{c}\text { Acceptance of the agency's } \\
\text { products: }\end{array}$ & Impact on the health status \\
\hline - Principles/Values & - HR management & HTA products (complete): & - Awareness & $\begin{array}{l}\text { Impact on the healthcare } \\
\text { system: }\end{array}$ \\
\hline - Governance & - Financial management & - Description & - Attitude & $\bullet$ Overall \\
\hline - Contract relationship & - Project management & • Quality & - Satisfaction & - Economic/Costs system \\
\hline - Colaborative relationships & - Strategy/Planning & - Cost & Use of HTA products: & - Equitability \\
\hline - Final resources & - Evaluation and/or research & - Opportunity & Symbolic & - Sustainability \\
\hline $\begin{array}{l}\text { - Human resources/ } \\
\text { personnel }\end{array}$ & - Comunications & - Relevance & $\begin{array}{l}\text { - Conceptual - change in } \\
\text { awareness, knowledge, } \\
\text { attitude in relation to } \\
\text { technology }\end{array}$ & \\
\hline - Comitttee/Structures/ & HTA processes: & Recommendations/ & - Instrumental - changes in & \\
\hline Functions & & Appraisals/Others: & policy or practice & \\
\hline - Organizational structure & $\begin{array}{l}\text { - HTA priority-setting and } \\
\text { selection }\end{array}$ & $\begin{array}{l}\text { - Research transference } \\
\text { or capacity development } \\
\text { events/products }\end{array}$ & Impact on technology: & \\
\hline - Data/Information systems & - Formulation of HTA issues & & - Innovation or adaptation & \\
\hline - Target-population & - Comissioning and follow-up & & - Research and development & \\
\hline \multirow[t]{5}{*}{ - Sources of requests } & - Data collection and analysis & & $\begin{array}{c}\cdot \text { Obsolescence/ } \\
\text { Replacement }\end{array}$ & \\
\hline & - Decisions/Recommendations & & & \\
\hline & $\begin{array}{c}\text { - Report preparation and } \\
\text { revision }\end{array}$ & & & \\
\hline & - Research disclosure/transfer & & & \\
\hline & • Appeals & & & \\
\hline
\end{tabular}

Source: adapted from Hailey ${ }^{11}$.

with two basic functions: (i) to generate accurate, pertinent and relevant information on health technology to improve healthcare services delivery and to subsidize health policy concepts and implementation; and (ii) to help in rationalizing procurement, adoption, management and dissemination of medical technologies at local, regional and national levels 20 . At first, CENETEC focused on medical equipment, but expanded its scope to include medical devices, medicationsand procedures.

The IETS is a public-private not-for-profit agency established in Colombia in September 2012. It assesses health technologies, evidencebased clinical guidelines and drug-use protocols, medical devices, procedures and treatments, to support policy makers and health practitioners in deciding what technologies are effective and most efficient, and therefore should be publicly funded.
The CONITEC replaced the Ministry of Health's Committee for Technology Incorporation (Comissão para Incorporação de Tecnologias do Ministério da Saúde-CITEC), and started to operate in 2011. CONITEC is connected to the Ministry of Health's Secretary of Science, Technology and Strategic Input (SCTIE), with assistance from the Department of Health Technologies Management and Incorporation (DGITS), created in 2012. CONITEC has the mandate to assist SCTIE in formulating policies, guidelines and goals for the incorporation, modification or exclusion of health technologies within the Brazilian Unified National Health System (SUS), as well as in the development and modification of medical protocols and therapeutic guidelines, in addition to suggesting updates of the National List of Essential Medication (RENAME).

After the creation of CONITEC, the process for the applicant to present requests and 
documents became a continuous flow, and the term for completion of the analysis was set at 180 days, extendable to an extra 90 days 21 . The term of 180 days was also established for the new technology to be incorporated into the SUS, after the deliberation is published in the Brazilian Federal Register. CONITEC recommendations should be validated by the Secretary of Science, Technology and Strategic Input, and submitted to the Minister of Health. After deliberation by the Minister of Health, the process should return to CONITEC, and be presented once again to the respective technical area for the incorporation or rejection of the technology.

\section{Nuclear dimension of HTA organizations}

The most frequently used parameters proposed in Hailey's theoretical model 11 (Figure 1 and Table 1) - context, human resources/personnel, financial resources, organizational structure, selection and priorization, formulation of HTA issues/scope of the assessment, HTA products and utilization of HTA products 12 - were used to organize the summary of the main studies identified through the narrative literature review.

\section{- Structure}

The structure dimension includes the parameters for context, human resources/personnel, financial resources and organizational structure.

\section{a) Context}

The organizations in charge of HTA processes may be on a local, regional, national and international level. On the local/regional level, HTA organizations address issues from local managers, healthcare services, health practitioners, insurance companies and other stakeholders. In recent years there has been an increase of HTA organizations on a hospital/local level 22. On a national level, the organization provides information to the federal government, national health system, policy makers and other stakeholders 23. The type of assessment is influenced by how the agency is admitted into the health system. The most important agencies are positioned on a national level 24 .

\section{b) Human resources/personnel}

Some organizations carry out their activities with their own teams; others coordinate and follow independent studies made by external bodies, such as universities, research institutions or groups of experts. While some agencies are pro- active in defining the studies to be conducted, setting priorities based on emerging issues and technological tracking, others are reactive and respond to demands from parties interested in specific studies 24 .

\section{c) Financial resources}

Public agencies are financed exclusively by the government, or have most of their funding provided by the government, but may receive some funding from the private sector. Private or forprofit HTA agencies are fully or mostly funded with private resources, and may receive a small contribution from the government 23 .

\section{d) Organizational structure}

The public model is disseminated the most. In it, the organizations are either included in the public healthcare system organization chart (regional/national level) or are a stand-alone, independent agency connected to the healthcare system. This is the model adopted in a number of countries with well-established HTA programs, such as the United Kingdom, France, Spain and Canada 24,25.

\section{- Processes}

The processes dimension includes selection and priorization, formulation of HTA issues/scope of the assessment.

\section{a) Selection and priorization}

A number of studies emphasize the lack of transparency in technology selection and priorization processes. Many HTA organizations do not have clear priority-setting processes that include selection methods and participation of stakeholders 26 , and only a little over half of the agencies use some explicit priority-setting process. Most agencies that claim to use priority-setting processes for the studies have a panel or committee to provide recommendations on the priorities 24,27 .

The most common criteria used by the agencies to establish their priorities are the medical and economic impact of the technology, the burden of disease, the budget impact, the availability of relevant information from HTA bodies or agencies, and the interest of governments, health practitioners and patients 27 . The priority criteria indicated by the selected agencies are presented in Table 2. The agencies NICE, AHRQ, CADTH and SBU were the ones with the greatest number of criteria. The criteria used by CENETEC and IETS were not identified. 
HTA organizations that are directly connected to governmental bodies often perform the assessments requested by the instances accountable for the incorporation and compensation; this means they have less autonomy in defining the priorities of the research agenda 28 . This is the case, for instance, of PBAC in Australia, that assesses the demands of medication manufacturers.

Most agencies try to operate with a certain degree of independence in relation to healthcare system managers, and work hard not to be directly involved in the existing conflicts of interests, without denying them, by means of transparent processes and policies 29 .

\section{b) Formulation of HTA issues/scope of the assessment}

The studies developed by HTA agencies adopt, in practice, narrow definitions that focus on efficacy, safety and efficiency.

While some agencies develop comprehensive studies that include all technologies that are interesting for healthcare systems, including those related to public health, most agencies limit their assessments to the study of new medications, devices, procedures or medical care programs that require major investments of capital. Worldwide, the approaches developed by the agencies for drugs are better established and more systematic than for other technologies. The assessments related to public health interventions, emerging technolgies and process technologies use diverse types of methodologies 30 .

\section{- Results}

\section{a) HTA products}

The products of INAHTA agencies differ in both terminology and the method used for their development. The development of some products is made under broadly accepted and well-established methods, and addresses the fundamental dimensions 31 .

The complete HTA reports should present more methodological rigor, and greater complexity in the analysis and quantity of information. Mini-HTA reports should present methodological rigor, but their scope is more limited, and the information presented is less comprehensive than the complete HTA reports. The Rapid Assessments, on the other hand, are less rigorous and more reduced in scope, and respond to urgent and specific needs of managers in a short period of time 31 .
The final products of HTA organizations and the recommendations drawn from the studies may be either discretionary or mandatory.

They are discretionary in nature when the considerations about their effectiveness and efficiency, at least of the technologies, and the recommendations on their incorporation in the health system are among the elements to be taken into account in the final decisions. In this case, the products are reports, medical-practice guidelines, etc. They are mandatory in nature when the political and legal conditions determine compliance with the recommendations. For that to be possible, there must be an overall political commitment and the establishment of policies so that healthcare managers and service providers accept the recommendations and manage the necessary resources to implement them 30 .

\section{- Product impact}

\section{a) The use of HTA products in changing health policies or practices}

The impact of products on the incorporation of health technologies depends on the political and institutional framework of the agencies. HTA organizations may play a direct regulatory role, as established by law, or their recommendations may be used by the regulatory body to define the rules for the incorporation of the technologies 23 .

Even with their having a "consultive", "recommendation-making" role, HTA agencies are considered important in the economic decisions upon which the treatments are funded by public health services. Recommendations from HTA agencies may be regulatory decisions, a fact that is more and more acknowledged by the judicial system. HTA bodies are not responsible for medication registration, but their studies may influence the purchase of medication and medical prescriptions by doctors and hospitals. The studies may also influence the strategies used by the pharmaceutical industry when they launch medications on national pharmaceutical markets 6 .

\section{Profile of the selected HTA organizations}

The narrative literature review enabled the construction of the profile of the selected 10 HTA organizations, summarizing the important dimensions that define the types of agencies, and their similarities or differences that reflect the national scenario (Table 3 ).

The types of technology assessed by the organization vary. For instance, in Sweden, the decision on the medication coverage is in charge of a specific body (Tandvårds-och läkemedels- 
Table 2

Priority-setting criteria for selection of technologies to be assessed.

\begin{tabular}{|c|c|c|c|c|c|c|c|c|c|c|}
\hline Criteria & PBAC * & SBU & CADTH & NICE & AHRQ & IQWiG ** & HAS *** & CENETEC \# & CONITEC \#\# & IETS \# \\
\hline Clinical impact & & $\checkmark$ & $\checkmark$ & $\checkmark$ & $\checkmark$ & & $\checkmark$ & & & \\
\hline Economic impact & & $\checkmark$ & $\checkmark$ & $\checkmark$ & $\checkmark$ & & $\checkmark$ & & & \\
\hline Burden of disease & & $\checkmark$ & $\checkmark$ & $\checkmark$ & $\checkmark$ & & $\checkmark$ & & $\checkmark$ & \\
\hline Budgeatry impact & & $\checkmark$ & $\checkmark$ & $\checkmark$ & $\checkmark$ & & & & & \\
\hline Expected level of interest & & & & $\checkmark$ & $\checkmark$ & & & & $\checkmark$ & \\
\hline Existing evidence & & & $\checkmark$ & & $\checkmark$ & & & & $\checkmark$ & \\
\hline Opportunity for revision & & & & $\checkmark$ & & & & & & \\
\hline Rate of use variation & & & & $\checkmark$ & & & & & & \\
\hline $\begin{array}{l}\text { Ethical, legal or psychosocial } \\
\text { implications }\end{array}$ & & $\checkmark$ & & & & & & & & \\
\hline $\begin{array}{l}\text { Technology of controversial } \\
\text { nature }\end{array}$ & & $\checkmark$ & & & $\checkmark$ & & & & & \\
\hline Existing alternatives & & & $\checkmark$ & & & $\checkmark$ & & & & \\
\hline $\begin{array}{l}\text { Questions about underutilization } \\
\text { or overutilization }\end{array}$ & & & & & & & & & & \\
\hline $\begin{array}{l}\text { High likelihood that results will } \\
\text { influence decision making }\end{array}$ & & & & $\checkmark$ & $\checkmark$ & & & & & \\
\hline Benefits from the assessment & & & & $\checkmark$ & & & & & & \\
\hline
\end{tabular}

AHRQ: Agency for Healthcare Research and Quality; CADTH: Canadian Agency for Drugs and Technologies in Health; CENETEC: Centro Nacional de Excelencia Tecnológica en Salud; CONITEC: Comissão Nacional de Incorporação de Tecnologias no SUS; HAS: Haute Autorité de Santé; IETS: Instituto de Evaluación Tecnológica en Salud; IQWiG: Institute for Quality and Efficiency in Health Care; NICE: National Institute for Clinical Excellence;

PBAC: Pharmaceutical Benefits Advisory Committee; SBU: Swedish Council on Technology Assessment in Health Care.

* PBAC in general does not define the medications to be assessed. It reviews the submissions (presented by the manufacturers) of new medication or of additional use of medications already listed on the national medication formulary (PBS);

** Nature and severity of the disease, magnitude of the therapeutic benefits, profile of side effects, convenience of use;

*** Impact in organizing healthcare, action planned by the applicant after the assessment;

\# No criteria used by CENETEC and IETS were identified;

\#\# Priority-setting process is based on the following criteria: epidemiological relevance; relevance for healthcare policy and services; advanced knowledge on the theme; operational feasibility; and social/judicial demands requiring actions from the State.

förmånsverket - TLV, Dental \& Pharmaceutical Benefits Agency, in English) that deals with medication coverage and pricing only. In England and Wales, the studies include an array of technologies (medications, devices, procedures, public health programs, screening programs, vaccines and services), and involve different committees, as presented on Table 3. Only two agencies (SBU and PBAC) limit the type of technology assessed (medications only); most assess different types of technologies (medications, procedures, devices, etc.)

The type of organization ranged from publiconly organizations to different public-private organization models to private-only organizations. Regardless of the type of organization, a point in common of all agencies is how careful they are in terms of bias regarding the interests of funding bodies and clients. For the conducted studies to reach their intended impact, all agencies are confronted with the need to be perceived as organizations that perform their activities independently. Literature suggests that placing national HTA agencies within the Ministry of Health of their countries is not satisfactory in the long run. One recommends that independent organizations be created, even if funded by public money, like SBU 32 .

Despite the differences found in the agencies investigated, a dominating model for coverage/ funding of new technologies in healthcare systems seems to exist. In this model (Figure 2), the process is started out with an application or request for coverage by a player (payer, provider, manufacturer or patient, depending on the 
country). Next, an HTA organization makes an assessment (technical and scientific data collection and synthesis process of the relevant aspects of the information, made by investigators) that will be used in the decision-making appraisal (political decision-making process by policy makers, taking into account the information collected in the assessment and other factors and values) 28 . During the HTA study processes, interaction between assessment-makers and decision-makers is expected and desirable. However, in general, the roles and responsibilities of HTA agencies and decision-makers are different 8 .

The institutional limitations and the organizations responsible for assessment and appraisal may vary, as one can see in England and Wales, where assessment is made by academic institutions and/or research institutes, like the University of York's Centrer for Reviews and Dissemination (CRD) or the United Kingdom's Health Technology Assessment Program and appraisal by NICE.

In Germany, decision-making is made by a single federal committee that makes decisions on all health technologies for outpatient clinics and hospitals. France has different appraisal committes for medications, medical procedures and devices, that are integrated in the same organization in charge of the assessments (HAS). The appraisal committees with decison-making power are those of NICE, TLV and G-BA 28,29. The Latin America organizations, more recently established, are placed within the Ministry of Health structure, with no well-defined attribution.

The criteria considered for decison-making is vague in the official documents, and their application in specific studies is hard to be identified 33 . The higher number of explicit decisionmaking criteria is for medications. A number of countries (Sweden, United Kingdom, Australia, Brazil) have considered cost-effectiveness as a relevant decision-making criterium in relation to medications. The political processes related to coverage medication are quite explicit and formalized in some countries, and HTA is clearly integrated, with laws to ensure it as a decisionmaking resource.

The ten selected organizations operate on a national level, according to a "national agency" model. According to the literature, this is not the only possible model; an alternative is a "network model", where a decentralized resarch group network would be coordinated by a national management body.

Regardless of the adopted model, the degree with which an HTA organization is able to achieve concrete changes in healthcare systems and services depends on the policy and regulatory characteristics of the context it operates. In other words, if the regulatory or professional bodies do not use the products from the agencies, and do not accept and implement the conclusions of HTA reports, the overall impact of HTA will likely be quite limited 34 .

\section{Final considerations}

Literature review and consultation of HTA organizations websites have revealed their progressive institutionalization in developed and developing countries. Methodological propositions that guide the studies to be conducted and that are adopted, more or less strictly by most agencies were disseminated. Methods standardization follows systematization propositions disseminated by INAHTA, EUnetHTA, ISPOR, among others. Each agency, however, has their particular profile, technology assessment, decision-making and implementation processes in accordance with their institutional and political framework and their respective health systems.

Despite differences related to the dimensions and profile of the organizations, HTA agencies share the challenges in setting the priorities of the technologies to be assessed, and in implementing their recommendations for national health policies.

The literature review on the relevant dimensions to assess agency effectiveness/impact and the profile of the selected organizations has contributed to a better understanding of the challenges faced in their countries.

The establishment of CONITEC in 2011 was a breakthrough in the process of HTA institutionalization in Brazil. However, one can consider it as being in the implementation stage, not yet having achieved methodological development, ample scientific legitimacy or the potential for a comprehensive policy-making role.

Upon analysis of HTA organizations that have adopted the "National Agency" model, this seems to be a suitable model for Brazil: a federal HTA agency that is independent, but articulated with government instances that decide about the funding of new technologies for the SUS, and that encourages the development of regional and hospital-based HTA organizations in order to promote a national, collaborative HTA network as part of health policy and for the scientific and technological development.

An agency that has ensured its mainly public financial funding would be able to have a permanent and technical staff, with solid methodological background and would be less sensitive to political changes and pressure from parties 
Table 3

Profile of the selected health technology assessment (HTA) organizations.

\begin{tabular}{|c|c|c|c|c|c|c|c|c|}
\hline Country & $\begin{array}{l}\text { Technology } \\
\text { assessed }\end{array}$ & $\begin{array}{l}\text { Starting of } \\
\text { operations }\end{array}$ & $\begin{array}{l}\text { Organization } \\
\text { in charge of } \\
\text { assessment }\end{array}$ & Type of organization & Funding & $\begin{array}{c}\text { Organization } \\
\text { in charge of } \\
\text { appraisal }\end{array}$ & Role & $\begin{array}{l}\text { Organization in } \\
\text { charge of overall } \\
\text { decisions }\end{array}$ \\
\hline Australia & Medications & 1953 & PBAC & $\begin{array}{c}\text { Independent statutory } \\
\text { authority }\end{array}$ & Government & PBAC & Consultative & Ministry of Health \\
\hline Sweden & Medications & 1987 & $\mathrm{SBU}$ & Governmental & Government & TLV & Regulatory & TLV \\
\hline Canada & $\begin{array}{l}\text { Medications; } \\
\text { devices; } \\
\text { procedures }\end{array}$ & 1989 & CADTH & Quasigovernmental * & Government & CADTH & Consultative & Ministry of Health \\
\hline $\begin{array}{l}\text { England } \\
\text { and Wales }\end{array}$ & $\begin{array}{l}\text { Medications; } \\
\text { devices; } \\
\text { procedures; public } \\
\text { health problems }\end{array}$ & 1999 & NHS CRD & $\begin{array}{l}\text { Special independent } \\
\text { health authority }\end{array}$ & Government & $\mathrm{NICE}$ ** & Regulatpry & NICE \\
\hline USA & $\begin{array}{c}\text { Medications; } \\
\text { devices; } \\
\text { procedures }\end{array}$ & 2003 & AHRQ & Governmental & Government & CMS & Consultative & CMS \\
\hline Germany & $\begin{array}{l}\text { Medications; } \\
\text { devices; } \\
\text { procedures }\end{array}$ & 2004 & IOWiG & Private & $\begin{array}{l}\text { Government + } \\
\text { private sector }\end{array}$ & G-BA & Regulatory & G-BA \\
\hline France & $\begin{array}{c}\text { Medical } \\
\text { and surgical } \\
\text { procedures; } \\
\text { medications; } \\
\text { devices; biologic } \\
\text { tests }\end{array}$ & 2005 & HAS & $\begin{array}{l}\text { Independent public } \\
\text { body }\end{array}$ & $\begin{array}{l}\text { Government + } \\
\text { private sector }\end{array}$ & 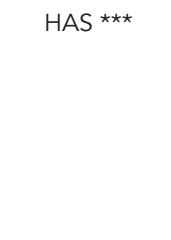 & Consultative & Ministry of Health \\
\hline Mexico & $\begin{array}{l}\text { Equipament } \\
\text { devices/ } \\
\text { Medications } \\
\text { procedures }\end{array}$ & 2004 & CENETEC & Governmental & & CENETEC & Consultative & Ministry of Health \\
\hline Brazil & $\begin{array}{l}\text { Medications; } \\
\text { healthcare } \\
\text { products; } \\
\text { procedures }\end{array}$ & 2011 & CONITEC & Governmental & Government & CONITEC & Consultative & Ministry of Health \\
\hline Colombia & $\begin{array}{c}\text { Medications; } \\
\text { devices; } \\
\text { procedures; } \\
\text { diagnostic tests }\end{array}$ & 2012 & IETS & Public-private & $\begin{array}{l}\text { Government + } \\
\text { private sector }\end{array}$ & IETS & Consultative & $\begin{array}{l}\text { Ministry of Health; } \\
\text { private-sector } \\
\text { decision makers }\end{array}$ \\
\hline
\end{tabular}

AHRQ: Agency for Healthcare Research and Quality; CADTH: Canadian Agency for Drugs and Technologies in Health; CENETEC: Centro Nacional de Excelencia Tecnológica en Salud; CMS: Centers for Medicare e Medicaid Services; CONITEC: Comissão Nacional de Incorporação de Tecnologias no SUS; G-BA: Gemeinsamer Bundesausschuss (Federal Joint Committee); HAS: Haute Autorité de Santé; IETS: Instituto de Evaluación Tecnológica en Salud; IQWiG: Institute for Quality and Efficiency in Health Care; NICE: National Institute for Clinical Ecellence; NHS CRD: National Health Service Centre for Reviews and Dissemination; PBAC: Pharmaceutical Benefits Advisory Committee; SBU: Swedish Council on Technology Assessment in Health Care; TLV: Tandvårds-och läkemedelsförmånsverket (Dental \& Pharmaceutical Benefits Agency).

* Funded by the government, but not a governmental body. Autonomous organization;

** Screening programs are appraised by the National Screening Committee (NSC), and vaccines are assessed by the National Coordinating Centre for Health Technology Assessment (NCCHTA) and appraised b y the Joint Committee on Vaccination and Immunisation (JCVINHS CRD), and the services are appraised by the National Specialist Commissioning Advisory Group (NCCAG);

*** Activities made by committees (committee to assess medical and surgical procedures, transparency committee, committee to assess health devices and technology) established within HAS. 


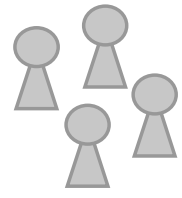

Provider Manufacturer Payer
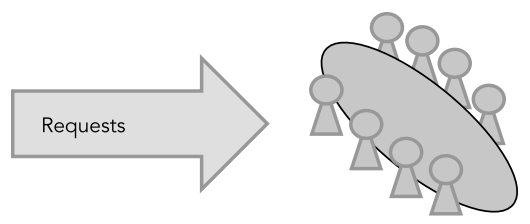

Decision-making body

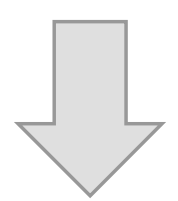

Policy recommendations/Decision
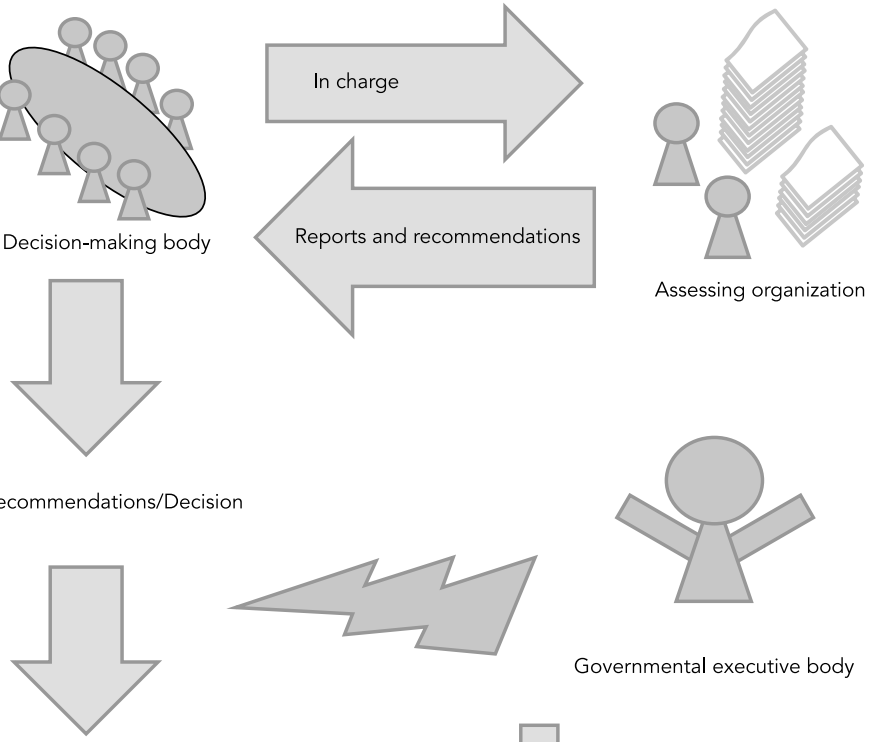

Governmental executive body

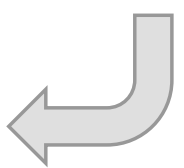

Decides

Source: adapted from Garrido et al. 28.

interested in the incorporation of technologies. Capable human resources are essential for the scientific legitimacy and the acceptance of the study results and recommendations presented in the technical reports.

The independence of the agency is essential to ensure transparency in the process to select and prioritize the technologies to be assessed. In the case of CONITEC, directly connected to a governamental instance (SCTIE), most technology assessments are made upon request of the public sector. A recent international study financed by the pharmaceutical industry questioned the clarity of the priority-setting criteria, pointing out the difficulties in requesting new assessments and the low participation of patients in the deliberation recommendations 35 .

The need for a more democratic participation of patients and representatives of society in technology selection and priority-setting criteria definition has been broadly discussed and encouraged in the international scenario ${ }^{36}$.

Permanent technical staff can better adapt the best practices to HTA studies, for these to be more complete and consistent. In regards to CITEC, which existed between 2008 and 2010, among the 103 studies conducted to support decisions, the predominance was of Rapid Assessment Reports (36/103), followed by Scientific Reports (26/103). Only 11.6\% (12/103) of these studies were economic assessments 37 . In CONITEC, between 2012 a 2015, the recommendation reports were also based on more simple studies about technology description and preliminary assessment of budgetary impact. Among the technologies recommended for incorporation, only $11.1 \%$ presented a full economic evaluation with incremental cost-effectiveness ratio calculation.

The reputation and credibility of an agency, the involvement of stakeholders and the quality of the products (reports, opinions, studies) presented are indicarted in the literature as the most important aspects for a stronger impact of the HTA agency 24.

In terms of the regulatory role of the agency, the institutional arrangement could be the clear separation of the institutional limits, and 
between the organizations responsible for the two tasks (assessment and appraisal), thus ensuring a privileged articulation with the decisionmaking instance to increase the influence of their recommendations and establish their effective policy activity potential.
The HTA institutionalization process in Brazil is continually developing, similarly to other countries. Its expansion and technical and political strengthening may contribute, significantly, with scientific, technological and innovation policies to effectively impacting health policies.

\section{Contributors}

H. M. D. Novaes and P. C. Soárez participated in the conception and design, data analysis and interpretation, writing and critical revision of the intellectual content of the article, approval of the final version to be published and are responsible for all aspects of the work in ensuring accuracy and integrity of every part of the paper.

\section{Acknowledgments}

To Institute for Health Technology Assessment (IATS) 
1. Banta D, Almeida RT. The development of health technology assessment in Brazil. Int J Technol Assess Health Care 2009; 25 Suppl 1:255-9.

2. Health Technology Assessment International. Book of abstracts of the 1st meeting of the PanAmerican Network of Health Technology Assessment. Edmontn: Health Technology Assessment International; 2011.

3. Battista RN, Hodge MJ. The evolving paradigm of health technology assessment: reflections for the millennium. CMAJ 1999; 160:1464-7.

4. Gauvin FP, Abelson J, Giacomini M, Eyles J, Lavis JN. "It all depends": conceptualizing public involvement in the context of health technology assessment agencies. Soc Sci Med 2010; 70:1518-26.

5. Hailey D, Nordwall M. Survey on the involvement of consumers in health technology assessment programs. Int J Technol Assess Health Care 2006; 22:497-9.

6. Thatcher M. Governance structures and health technology assessment agencies: a comparative approach. London: Department of Government, London School of Economics and Political Science; 2010.

7. Hailey D, Juzwishin D. Managing external risks to health technology assessment programs. Int J Technol Assess Health Care 2006; 22:429-35.

8. Hailey D, Babidge W, Cameron A, La D. HTA agencies and decision makers: an INAHTA guidance document document. Edmonton: International Network of Agencies for Health Technology Assessment; 2010.

9. Roughead EE, Gilbert AL, Vitry AI. The Australian funding debate on quadrivalent HPV vaccine: a case study for the national pharmaceutical policy. Health Policy 2008; 88:250-7.

10. Velasco M, Perleth M, Drummond M, Gürtner F, Jørgensen T, Jovell A, et al. Best practice in undertaking and reporting health technology assessments. Working group 4 report. Int J Technol Assess Health Care 2002; 18:361-422.

11. Hailey D. Elements of effectiveness for health technology assessment programs. Edmonton: $\mathrm{Al}$ berta Heritage Foundation for Medical Research; 2003. (HTA Initiative, 9).

12. Wanke M, Juzwishin D, Thornley R, Chan L. An exploratory review of evaluations of health technology assessment agencies. Edmonton: Alberta Heritage Foundation for Medical Research; 2006. (HTA Initiative, 16)

13. Jonsson E. History of health technology assessment in Sweden. Int J Technol Assess Health Care 2009; 25 Suppl 1:42-52.

14. Menon D, Stafinski T. Health technology assessment in Canada: 20 years strong? Value Health 2009; 12 Suppl 2:S14-9.

15. Battista RN, Côté B, Hodge MJ, Husereau D. Health technology assessment in Canada. Int J Technol Assess Health Care 2009; 25 Suppl 1:53-60.

16. O’Donnell JC, Pham SV, Pashos CL, Miller DW, Smith MD. Health technology assessment: lessons learned from around the world: an overview. Value Health 2009; 12 Suppl 2:S1-5.
17. Drummond M, Sorenson C. Nasty or nice? A perspective on the use of health technology assessment in the United Kingdom. Value Health 2009; 12 Suppl 2:S8-13.

18. Sullivan SD, Watkins J, Sweet B, Ramsey SD. Health technology assessment in health-care decisions in the United States. Value Health 2009; 12 Suppl 2:S39-44.

19. Fricke FU, Dauben HP. Health technology assessment: a perspective from Germany. Value Health 2009; 12 Suppl 2:S20-7.

20. Gómez-Dantés O, Frenk J. Health technology assessment in Mexico. Int J Technol Assess Health Care 2009; 25 Suppl 1:270-5.

21. Ministério da Sáude. O que muda da antiga CITEC para a atual CONITEC no processo de incorporação de tecnologias no SUS 2011. http:// portal.saude.gov.br/portal/arquivos/pdf/conitec doc_070212.pdf (accessed on 27/Feb/2012).

22. Gagnon MP. Hospital-based health technology assessment: developments to date. Pharmacoeconomics 2014; 32:819-24.

23. European Network for Health Technology Assessment. EUnetHTA handbook on HTA capacity building. Barcelona: Catalan Agency for Health Technology Assessment and Research; 2008.

24. Moharra M, Kubesch N, Estrada MD, Parada A, Cortes M, Espallargues M. Survey report on HTA organizations. Barcelona: Catalan Agency for Health Technology Assessment and Research; 2008.

25. European Network for Health Technology Assessment. WP8 on systems to support HTA in countries with limited institutionalisation of HTA. Copenhagen: European Network for Health Technology Assessment; 2007. (WP8 Technical Report).

26. Sorenson C, Drummond M, Kanavos P. Ensuring value for money in health care: the role of health technology assessment in the European Union. Copenhagen: WHO Regional Office for Europe; 2008. (Observatory Studies Series, 11).

27. Noorani HZ, Husereau DR, Boudreau R, Skidmore B. Priority setting for health technology assessments: a systematic review of current practical approaches. Int J Technol Assess Health Care 2007; 23:310-5.

28. Velasco Garrido M, Kristensen F, Nielsen C, Busse R. Health technology assessment and health policy-making in Europe: current status, challenges and potential. Copenhagen: WHO Regional Office for Europe; 2008. (Observatory Studies Series, 14).

29. Sorenson C, Chalkidou K. Reflections on the evolution of health technology assessment in Europe. Health Econ Policy Law 2012; 7:25-45.

30. Organisation for Economic Co-operation and Development. The OECD Health Project. Health technologies and decision making. Paris: Organisation for Economic Co-operation and Development; 2005 
31. Merlin T, Tamblyn D, Ellery B; INAHTA Quality Assurance Group.A. What's in a name? Developing definitions for common health technology assessment product types of the International Network of Agencies for Health Technology Assessment (INAHTA). Int J Technol Assess Health Care 2014; 30:430-7.

32. Martelli F, La Torre G, Di Ghionno E, Staniscia T, Neroni M, Cicchetti A, et al. Health technology assessment agencies: an international overview of organizational aspects. Int J Technol Assess Health Care 2007; 23:414-24.

33. Velasco-Garrido M, Schreyogg J, Stargardt T, Busse R. Identification of health baskets in nine EU countries. Rev Fr Aff Soc 2006; 6:63-88.

34. Lehoux P. The problem of health technology: policy implications for modern health care systems. New York: Routledge; 2006.

\section{Resumo}

A avaliação de tecnologias em saúde (ATS) está consolidada enquanto prática científica e tecnológica. $O$ objetivo do estudo é identificar organizações de ATS de diferentes contextos e analisá-las de acordo com dimensões relevantes na avaliação de sua efetividadelimpacto, buscando contribuir com os desafios enfrentados no contexto nacional. Revisão narrativa da literatura, realizada em bases de dados e web sites de organizações de ATS. Existem processos de desenvolvimento das atividades bem estabelecidos em todas as organizações. Elas apresentam particularidades no seu perfil, nos processos de avaliação, decisão e implementação das tecnologias que influenciam o seu impacto potencial sobre os sistemas de saúde. As agências compartilham os desafios de priorização das tecnologias a serem avaliadas e implementação das suas recomendações. O fortalecimento técnico e político do processo de institucionalização da ATS no contexto nacional poderá contribuir com as políticas científicas, tecnológicas e de inovação, impactando de forma efetiva as políticas de saúde.

Avaliação de Tecnologias de Saúde; Tomada de Decisões; Políticas Públicas de Saúde, Desenvolvimento Sustentável; Inovação
35. Wilsdon T, Fiz E, Haderi A. A comparative analysis of the role and impact of health technology assessment: 2013. Washington DC: Charles River Associates; 2014.

36. Menon D, Stafinski T. Role of patient and public participation in health technology assessment and coverage decisions. Expert Rev Pharmacoecon Outcomes Res 2011; 11:75-89.

37. Novaes HMD, Elias FTS. Uso da avaliação de tecnologias em saúde em processos de análise para incorporação de tecnologias no Sistema Único de Saúde no Ministério da Saúde. Cad Saúde Pública 2013; 29 Suppl 1:S7-16.

\section{Resumen}

La evaluación de tecnologías en salud (ETS) está consolidada en cuanto práctica científica y tecnológica. El objetivo del estudio es identificar organizaciones de ETS de diferentes contextos y analizarlas, de acuerdo a dimensiones relevantes en la evaluación de su efectividad/impacto, procurando contribuir a los desafíos existentes en el contexto nacional. Revisión narrativa de la literatura, realizada en bases de datos y páginas web de organizaciones de ETS. Existen procesos de desarrollo de las actividades bien establecidos en todas las organizaciones. Éstas presentan particularidades en su perfil, en los procesos de evaluación, decisión e implementación de las tecnologías que tienen influencia por su impacto potencial sobre los sistemas de salud. Las agencias comparten los desafios de priorización de las tecnologías para que sean evaluadas e implementación de sus recomendaciones. El fortalecimiento técnico y político del proceso de institucionalización de la ETS en el contexto nacional podrá contribuir con políticas científicas, tecnológicas y de innovación, teniendo impacto de forma efectiva sobre las políticas de salud

Evaluación de las Tecnologías de Salud; Toma de Decisiones; Políticas Públicas de Salud; Desarrollo Sostenible; Innovación
Submitted on $24 / \mathrm{Feb} / 2015$

Final version resubmitted on $27 / \mathrm{Jul} / 2015$

Approved on 20/Oct/2015 